\title{
Manufacturing Consent: a corpus-based critical discourse analysis of New Labour's educational governance
}

\author{
Jane Mulderrig \\ University of Sheffield
}

\begin{abstract}
This paper presents selected findings from a historical analysis of change in the discursive construction of social identity in UK education policy discourse from 1972-2005. My chief argument is that through its linguistic forms of self-identification the government construes educational roles, relations and responsibilities not only for itself, but also for other educational actors and wider society. More specifically, I argue that New Labour's distinctive mode of selfrepresentation is an important element in its hegemonic project, textually manufacturing consent over its policy decisions, and helping to articulate its selfstyled 'enabling' model of governance. As evidence for these claims I discuss two prominent trends in New Labour's education policy rhetoric, which I characterise as 'personalisation' and 'managerialisation'. Respectively, these relate to the discursive representation of social identity and social action.
\end{abstract}

KEYWORDS: Managerialism, Personalisation, Corpus-based Critical Discourse Analysis, New Labour, Educational Governance

\section{Introduction}

My aim in this paper is to demonstrate the rhetorical novelty displayed by New Labour in its governance of education. This special issue of EPAT begins from the premise that strategies of domination are often hidden beneath (and reified through) everyday language. The ways in which we routinely define ourselves individually and collectively position us and others as social subjects (Foucault, 1971), thereby structuring social relations of power and domination. This paper presents selected findings from a historical analysis of change in the discursive construction of social identity in UK education policy discourse. My chief argument is that through its linguistic forms of self-identification the government construes educational roles, relations and responsibilities not only for itself, but also for other educational actors and wider society. More specifically, I argue that New Labour's distinctive mode of self-representation is an important element in its hegemonic project, textually manufacturing consent over its policy decisions, and helping to articulate its selfstyled 'enabling' model of governance. As evidence for these claims I discuss two prominent trends in New Labour's education policy rhetoric, which I characterise as 'personalisation' and 'managerialisation'. Respectively, these relate to the discursive representation of social identity and social action. 


\section{Discourse, Education, and the Capitalist State}

The findings presented in this paper stem from a much larger project ${ }^{1}$ that examined patterns of historical change in how government discourse represents and legitimates the distribution of power and institutional organisation (thus governance) of UK state education (Mulderrig, 2006). This study employed corpus linguistic methods in a longitudinal critical discourse analysis (Chouliaraki \& Fairlcough, 1999; Fairclough, 2003) of education policy texts dating from the Heath government of 1972 to that of Blair in 2005 (Mulderrig, 2006). To contextualise the study I used neo-Marxist state theory (Jesssop, 1999; 2002), Colin Hay's more localised account of the British political context (Hay, 1996, 1999), and educational sociology (e.g. Dale, 1989; Tomlinson, 2001; Trowler, 2003). During the time period examined Britain adopted a range of strategies to respond to and, importantly, help to shape a number of major political, economic and cultural changes. These include an overall shift from an industrial to a so-called 'knowledge-based' and globalised economy; from a welfare to what has been dubbed a 'workfare' approach to social policy (Jessop, 1994; 2006); as well as the emergence of new forms of governance (Newman, 2001), and the increasing political emphasis on creating a lifelong 'learning society' (Dale and Robertson, 2006). Particularly important were demands for privatisation, marketisation and welfare retrenchment.

In education, this period saw structural and ideological pressures to align education more closely with economic policy goals. Indeed, the 'vocabularies of motives' (the discourses that articulate the goals and values of education) were changed, redefining the nature and purposes of education (Dale 1989) ${ }^{2}$. This discursive shift prepared the way for further 'modernisation' programmes by a reinvented Labour party that put economic competitiveness at the centre of its political agenda. The chief aim of this study was to take policy discourse as the lens through which to explore the dynamics and tensions of education policy-making in this context of profound political and economic change, and specifically to explore the extent to which economic concerns do in fact infiltrate the discourse of educational governance (see Mulderrig, 2008, for an analysis of economic discourses from Thatcher to Blair). Critical discourse analysis, in dialogue with political economy and educational sociology, is ideally suited to such an investigation, since it is premised on the socially embedded nature of discourse. This allows us to argue that education policy texts do not exist in a social vacuum, but have a complex, historically changing, and mutually constitutive relationship with their social context.

A critical analysis of policy discourse explores and assesses the sociological significance of the textual strategies that emerge from this dialectical relationship. The main focus of analysis was on the textual strategies by which shifting relations of power in educational governance were negotiated and legitimated during this period. The social theorist Nikolas Rose (1999) commented that a key factor in successfully negotiating governmental legitimacy is the institutional identity it projects to the public. Therefore the government's social identity was one of the main points of inquiry in the linguistic analysis, the findings of which were then interpreted in relation to a sociologically informed understanding of the historical context. In this sense the primary focus was on how the government represents and legitimates its own 'acts of governing' (Mulderrig, 2009a), as well as how it represents education (including its functions) (Mulderrig, 2007; 2008) and its actors (Mulderrig, 2003b; 2007). 


\section{Corpus-based Critical Discourse Analysis}

Critical discourse analysis (CDA) is a problem-oriented interdisciplinary research tradition within the social sciences, subsuming a variety of approaches, each with different theoretical models, research methods and agenda (see Fairclough et al., 2009 for an overview). Unlike some forms of discourse-based research, CDA does not begin with a fixed theoretical and methodological stance. Instead, the research process begins with a particular topic - here, the governance of education in the 'post-Fordist' era - and the theoretical and methodological tools are then developed as the object of research is progressively refined. Corpus linguistics is a computer-based method for analysing large bodies of textual data (McEnery \& Wilson, 1996). Its incorporation in CDA has been a relatively recent development (e.g. Koller \& Mautner, 2004; Mautner, 2005; 2009; applied to educational research: Mulderrig, 2003a; 2003b; 2008; 2009a; 2009b). The choice to combine them in this study was motivated partly by a wish to develop a systematic and thus replicable form of critical discourse analysis. Furthermore, I wished to investigate patterns of change over a significant period of time. Robust findings could thus only be generated by examining a very large corpus of data (500,000 words), which in turn requires the use of corpus software tools. There is also a heuristic value to this combined approach in directing the analyst's gaze in unexpected and often fruitful directions. For example, I have elsewhere used 'keywords" ${ }^{3}$, analysis to investigate the historical rise and fall of the most prominent political discourses in relation to UK education (Mulderrig, 2008).

The corpus analysed comprises 17 digitised policy consultation documents ('White Papers'), which were subdivided into four periods to allow comparison over time. Corpus software tools were used to direct the preliminary search for patterns of self-representation; I then progressively added layers of interpretation to the findings by drawing on Fairclough's approach to CDA (1992; 2000; 2003; 2005), and Van Leeuwen's sociosemantic model of social action and legitimation (1995; 1996; 2007). In the first stages of the analysis I ran concordance searches for the two most prominent (in terms of 'keyness') forms of self-representation used by the government: we and government (respectively, around 2600 and 2000 occurrences). I then used systemic functional grammar (Halliday, 1994) to code each instance according to action-type ${ }^{4}$ and the degree of agency represented for the government. Two key trends in the corpus emerged from this stage of the analysis, both of which appertain to the New Labour government: 1) the emergence of an increasingly personalised, inclusive identity represented for the government, and 2) evidence of an increasingly managerial identity constructed for the government, and in particular a relatively regularised linguistic realisation of managerialism in the form of a particular type of action and power relation that I term 'managing action'. I discuss each trend below.

\section{'Personalisation'}

Following Van Leeuwen (1996), the choice of the term the government impersonalises the representation through 'institutionalisation' (abstractly representing a group of people by means of their institutional belonging), whereas the use of the personal pronoun we personalises it, foregrounding +human ${ }^{5}$ semantic properties $^{6}$. While this pronoun is rarely used by the previous governments ${ }^{7}$, under New Labour it eventually displaces the term 'government' altogether. Moreover, as 
the graph below illustrates, there is a dramatic surge in the overall textual prominence of the government ${ }^{8}$, almost doubling the figure for the preceding period, with an average figure of $1.34 \%$ compared with $0.74 \%$ under Major.

\section{Graph 1}

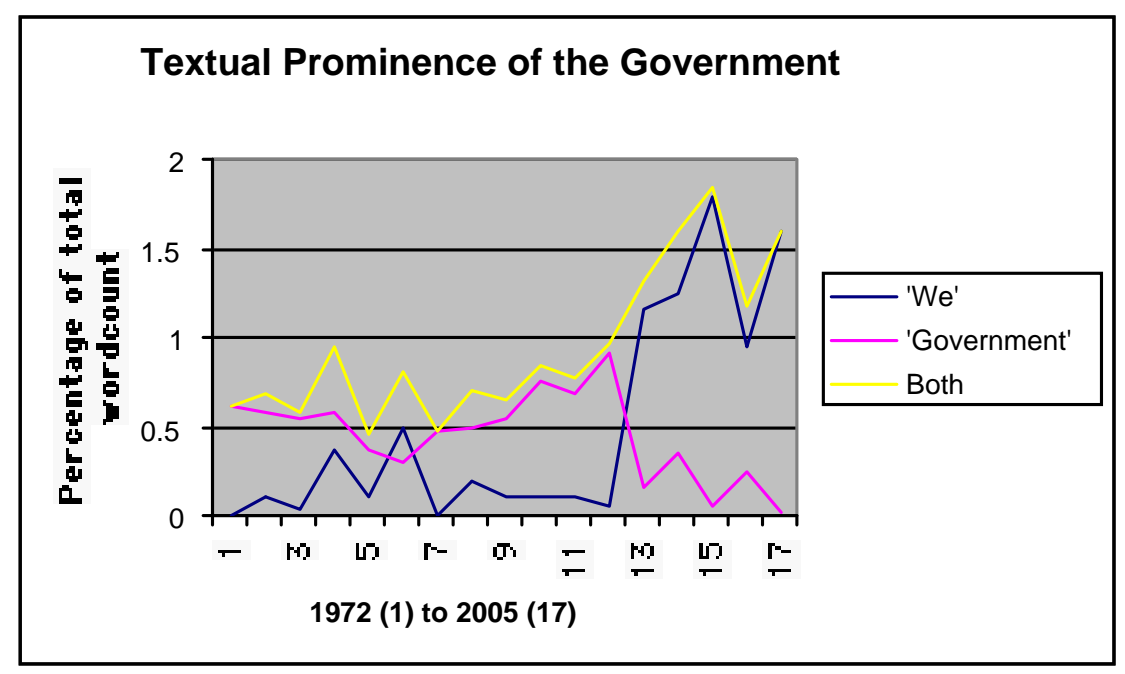

As the graph clearly shows, New Labour is not a retreating government. Undoubtedly, the Blair government represents a dramatic and unequivocal shift in self representational style: of the 2654 instances of we throughout the entire corpus, 91\% of them (2421) occur under Blair. In fact, this pronoun is the second highest keyword under New Labour. In any genre, for a common grammatical word like we to be the second highest keyword is really quite remarkable and suggests that under New Labour $^{9}$ this pronoun is a significant strategic element in building a more inclusive political identity. The increasing use of the pronoun 'we', along with other discursive strategies, is part of a general trend in recent decades towards the 'personalisation' of public discourse (Fairclough, 1992; Habscheid, S., \& Knobloch, 2008; Petersoo, 2007). This can be viewed as a symptom of the increased economic importance of language in the Post-Fordist era (for a discussion, see Fairclough et al., 2009). In a context where commercial (and political) profitability and success increasingly rely on the 'face' institutions present to the public, this increases strategic concern with design, presentation and communication techniques. More generally, it may signal what Fairclough (1992) terms a process of 'democratisation' of discourse, of which one aspect is a tendency towards more informal language and the removal of explicit textual markers of power asymmetries.

I would argue that in the realm of politics it has particular significance; by collapsing the distinction between the government and the people, this mode of representation draws citizens into the very processes of governing, thus implicating them in policy decisions. When adverts or commercial organisations adopt this 'personalised' collective identity, the effect is not the same. It may generate greater affinity and identification with the brand or company in question (as it is doubtless intended to), but it does not draw us into the governance processes of that organisation. In New Labour discourse the pronoun we may be favoured over the government, with its authoritarian tone, in order to create a discourse more consonant with its claims to participatory democracy, and a 'stakeholder' vision of citizenship. However, as Fairclough (ibid.) observes, democratised discourse can in fact simply be 
a means of disguising power asymmetries, rather than removing them. Moreover, because we potentially includes the reader (which at times in the data it does), it allows the government to claim consensus on its vision of things, thereby removing the space for dialogue and alternative voices which one would expect of policy consultations, thereby having a de-democratising effect.

\section{The Meaning of We}

The collective pronoun we is semantically complex. Its meaning can be 'inclusive' (including the reader/hearer) or 'exclusive' (excluding them; thus referring only to the government). I coded every occurrence in the data according to these categories. However, the distinction between them is in fact not always clear. The variability in meaning and use of we is not merely a technical issue, but of considerable analytical significance. This is particularly true in political discourse. Representational choices play an important role in constructing collective identities and the allocation of roles and responsibilities within and beyond the state. They are therefore a key textual mechanism for (re)drawing lines of inclusion and boundaries of political responsibility. Thus in my analysis I explicitly include a third category of ambivalent cases, given their highly significant role in New Labour's mode of governance and legitimatory rhetoric. The following is a sample extract from the concordance ${ }^{10}$ findings from the data. Each instance is coded as [I] inclusive, [E] exclusive, or [?] ambivalent. The surrounding text in this extract provides some evidence of the way each type is used. The cases of exclusive we are making promises or statements about the government's own actions. Cases of inclusive we make evaluative statements about the nation's activities, while many of the ambivalent types are modalised (expressing obligation, possibility or likelihood). In fact, these functional patterns represent a highly systematic and distinctive rhetorical pattern under New Labour.

\section{Concordance Results for 'We'}

The Skills Challenge and How [E]We Will Meet It. Skills for Employers, portion of skilled, qualified people[?]We will not achieve a fairer,

a fairer, more inclusive society if [?]we fail to narrow the gap between the skills rich and the skills poor.

is a contribution to the work [E]we are engaged in with our European partners

er the long term. To achieve that [?] we need to act in five key areas the Union, where it is vital that [?]we identify best practice and share ice and share our experiences. [I]We all know that skills

We all know that skills matter. But [I]we also know that as a nation we do But we also know that as a nation [I]we do not invest as much in skills as e do not invest as much in skills as [I]we should. Compared with other Compared with other countries [I] we perform strongly in some areas such as higher education. But [I] we have major shortfalls in eet differing consumer demands [E]We are under no illusion about are clear about their contribution [?] we can make much faster progress towards the shared objective. [?] We must put employers' needs respond directly to those needs[?] We must raise ambition in the demand for skills

\section{The Functions of We}


Having analysed the clausal environment of every instance of $w e^{11}$, I found marked patterns in the functional distribution of each type. To summarise, exclusive we represents the government's own past, present or future actions; in particular there is a systematic correlation between exclusive we and boasts about the government's actions. Cases of inclusive we frequently make comparative or evaluative statements about the nation's activities, often in competitive terms. Ambivalent types tend more frequently to be modalised (expressing some sort of need or obligation) as in the last two examples above.

\section{Inclusive We and the Logic of Competitiveness}

Although comparatively few in number, clearly inclusive cases of we more frequently occur in policy documents jointly published with the Department for Trade and Industry, whose remit also includes economic and social policy in general, rather than solely education. Examples typically draw comparisons between Britain and its international competitors or the Britain of today and that of the past (e.g. we lag behind our competitors, we have a workforce with worldclass ICT skills, we are part of a global environment, we have some first class schools, we have particular skills gaps, we compare well at the HE level, if we are to sustain our place as a leading global economy). The last example illustrates the role of assumptions in claiming a commonly held neoliberal value system. It contains a conditional semantic relation 'if $\mathrm{X}$ then $\mathrm{Y}^{\prime}$, and contains a significant degree of tacit information. First, it assumes that we would indeed wish to sustain our place as a 'leading global economy'. This is in addition, of course, to the presupposition that we are a leading global economy (on presuppositions, see Chilton, 2004). This is an example of what Martin (1991) terms 'buried reasoning', whereby the reasoning involved in some statement is hidden through abstraction. Here the evaluative premises that constitute the logical scaffolding of the statement are hidden. Unpacking the example, we can recover this and other information lost in the different generalising transformations it has undergone:

\section{(If we are to sustain) NG[[our place] as [a leading global economy]]}

This clause is structurally dependent on what comes next in the text (an evaluative statement about what we 'must' do in order to 'sustain our place'). The goal of the process (sustain) is contained in the nominal group (NG), which contains a number of assumptions. Firstly, it contains an embedded evaluation which we might 'unpack' as: we have a place as a leading global economy. This potentially refutable assertion is turned into a fact-like attribute 'our place' through the grammatical choices made. As a result its deniability is reduced - as Halliday and Martin observe, 'you can argue with a clause, but you can't argue with a nominal group' (1993: 39). Secondly, a further embedded nominal group functions as the qualifier: a leading global economy. The subject of the clause we is thereby constructed as the equivalent to the entity economy. I would argue that equivalence draws on the logic of a neoliberal value system, which is also triggered by the attributes leading and global. These help construe a positively evaluated state of affairs which we would 'naturally' wish to sustain.

Through this type of evaluative statement, a nation state is represented as equivalent to its economic system, and then ascribed characteristics whose value is 
intertextually derived. The attributes global and leading do not semantically encode a positive or negative value in the same way as lexis whose chief semiotic function is evaluation (for instance splendid or terrible). In the above extract, a global economy is one which is valued on the basis of the scale on which it is able to operate. The value triggered is one of power relative to other economies, achieved through geographical 'reach'. Similarly, the predication leading again values the entity in terms of power, this time its ability to direct and affect others. These two dimensions of evaluation are coherent only within the structural framework of competitive activity, the basic form of social relation around which capitalist economic activity is organised. Taken together, I would therefore argue that the evaluative components of this clause are derived intertextually from a neoliberal discourse of competitiveness promulgated notably by the EU (Muntigl et al., 2000) - wherein countries' economies are represented as less confined to national territory, but rather operating across an increasingly transnational or 'global' competitive terrain, and where national economic success is measured in terms of relative market position.

\section{Ambivalent $W e$ and the legitimation of policy injunctions}

The most frequent use of ambivalent we (75\% of the time) is to represent exhortations with varying degrees of explicitness. Thus under New Labour there is an increased tendency to obfuscate social responsibility, in respect of both the obligations and desires that constitute the rationale for policy proposals. In an argumentation strategy typical of this genre, the government outlines the problems it is attempting to address when it comes to formulating policy in a problem-solution textual pattern. This causal relation between policy problem and policy solution is represented in terms of social necessity. Policies are thereby represented as meeting some form of shared need, where the (grammatical) subject of that need is the ambivalent we. The necessity is of two main types: a duty to act in some way (we must do $X$ ), or a particular felt need (we need $X$ ). In both cases the government effectively acts as a spokesperson, making statements on behalf of an unspecified collective. This is a strategy associated with socially powerful actors: 'like the 'power of prediction', the power of making statements on behalf of others, or indeed on behalf of 'all of us'...is a power which has an uneven social distribution, and is important for identification' (Fairclough, 2003: 171). The actual modalizations involved contain high degrees of deontic commitment (obligation) - thus, we must do vs we might do. In effect, therefore, the textual patterns found in the New Labour data represent social imperatives, not possibilities. The ambivalence of the subject (we) serves to mitigate any face threat by spreading the responsibility across a collective social subject.

The verbs ensure and make sure are frequently used in New Labour policy discourse to construct a managerial role for the government, steering others' actions. They form part of a larger 'grammar of governance' that plays a significant part in constructing a so-called 'enabling' modality of governance (Mulderrig, 2009b). They are similarly used in this hortatory context. In all but two cases, the remainder of the clause thus represents a managed actor or actors engaged in some process. The following are typical examples: [we must ensure that] all [pupils] have the skills and capabilities; people learn how to be creative and all schools deliver high standards.

\section{The Hegemonic Role of We: inclusion and shared responsibilities}


The success of the strategy of 'personalisation' in legitimating policy rests on semantic slippage across the different types of we. Often this slippage works simply by juxtaposing various statements containing the different forms of we. This extract illustrates how the strategy can be used to legitimate a neoliberal model of citizenship through the assumption of a shared consensus.

Beyond these subjects, we[?] need to be confident that everyone leaving education is equipped to be an informed, responsible, active citizen. In an ever more complex, interdependent world, where an engaged population is crucial to the health of our society, we[E] continue to put citizenship at its heart too. And we[?] need real confidence that our schools and colleges really do give young people the skills they need for employability. (DFES, 2005, 14 - 19 Education and Skills)

In the extract ambivalent we textures an hortatory evaluation about the role of education in socialisation. The second sentence paints a picture of the global economic context for education policy in which individual responsibility is paramount. The next sentence juxtaposes this citizenship argument with an economic responsiveness discourse of education, where the emphasis is on the acquisition of skills to enhance individual employability. While not explicitly conflating them, this textual arrangement construes a close association between employability and citizenship. Significantly, where such workfarist discourse is evoked the agency of the evaluation is absorbed in an ambivalent we. Throughout the Blair data the semantic slipperiness of we helps construct an apparent consensus on the nature of the world we live in and the inescapable responsibilities this creates. In turn, this supposedly inexorable context of global economic competitiveness is used to preface and legitimate policy proposals made by the government. Through this rhetorical device, government policy decisions effectively become harder to criticise since their legitimacy rests on global economic forces apparently beyond the government's control. The legitimation is implicit, triggered only by juxtaposing: 'we (I) live in a changing world', 'we (?) must respond with X activity', and 'we (E) will provide the following policy solution'. Moreover, given the way this device exploits the semantics of the pronoun we, the political effect is that we are now all implicated in the rationalisation and legitimation of policy. In this way, political consensus is assumed, not jointly produced.

\section{'Managerialisation'}

Turning to a second key trend identified in the data, I found that the traditional authority and control of the government has progressively given way to a more managerial form of institutional identity. This also extends to the activities represented for the government, which are increasingly concerned with controlling and monitoring the activities of an ever wider range of actors. The concept of 'governance' has come to occupy a prominent place in academic inquiry over the last two decades. In part this is a reflection of substantive changes in the way advanced liberal states predominantly organise their economic, political and social activities. We might characterise this as a move away from the rigid hierarchies of bureaucracy, towards a new form of 'soft power' - or persuasive power (Nye, 2004) - involving the coordination of complex networks of self-governing actors.

In the last quarter of the $\mathrm{C} 20^{\text {th }}$, the decline of the post-war bureaucratic regime and its centrally regulated industrial economy gave way to the gradual emergence of a 
new 'diagram' of relation between government, expert and citizen. It is characterised by technologies of self-governance, audit, and appraisal (Rose, 1999). A key figure in this new style of governing is the active citizen-consumer, empowered and responsibilised to make choices that further their own interests or those of the 'community'. Importantly, this requires a shift in power relations: citizens must have greater agency over their own actions; the government less direct control. As Rose puts it, 'the social state gives way to the enabling state' (1999: 142). We might posit that such an 'autonomising' model of democracy would be capable of absorbing potential conflict by instead offering choice, opportunity, possibility, and so forth. With greater reliance on individual volition, this form of 'soft power' would seem to be less coercive and more intrinsically democratic. However, I will argue that the discursive forms this takes, do not so much remove coercion as mask it in more subtle forms.

As discussed above, I used systemic functional grammar to analyse each instance of we and the government according to action-type. In general, this revealed an increasingly managerial identity constructed for each successive government through a variety of verb forms (e.g. lead, direct, consider, discuss, evaluate) and textual collocates (e.g. appraisal, benchmark, delivery) which seemed to confirm the rise in public sector managerialism posited in the literature (Clarke and Newman, 1997). What the literature could not predict, however, was the proliferation under New Labour of a particular linguistic construction which helps enact this managerial model of governance in a very subtly hegmonic way though a specific type of action and power relation. Drawing on both sociological theory and the empirical data I call them 'managing actions'.

\section{Managing Actions}

As the name suggests the term 'managing actions' refers to a set of lexicogrammatical resources for getting people to do things. Typical examples are ensure, require, expect, support and help. Rather than the direct agent of processes, the government is the instigator or controller of others' actions. Some cases involve causative-type verbs like enable or allow followed by a managing action realised in various forms. However, not all examples involve causative structures or even verbs at all. For example, in some cases the managing action may be nominalised. In fact managing actions overlap with a variety of surface forms. Moreover, systemic functional grammar fails to capture their sociological significance, thus following Van Leeuwen's approach $(1995 ; 1996)$ I formulated a sociosemantic typology for these actions. I then analysed their distribution and function throughout the data.

The increase in 'managerialism' is closely associated with more general trends in governance since the late 1980s (Clarke \& Newman, 1997; Newman, 2000; 2001). As this model of governance progressively displaces others, it necessarily involves the renegotiation of power relations. Thus, my typology attempts to move beyond the purely textual level in order to capture the important role of social power in the discursive representation and enactment of management. In the example We will take powers to allow schools greater freedom to innovate, power relations are semantically encoded in the lexical forms allow and freedom. In other cases, they are assumed, as in examples representing the government's expectations of others, where the successful instigation of others' actions is vested in its institutional authority. Thus, forms of managing vary in coerciveness and intersect with the power relations between the participants. It follows that these relations may in part be reproduced or 
transformed through the forms of management represented. For example there is a tendency for more explicitly coercive forms of management, as encoded in the semantics of the verb (expect, require) to be textured with institutional actors whose power and influence we know to be in decline, namely LEAs (Dale, 1989; Trowler, 2003). Conversely, actions which semantically encode greater freedom and/or less coercion (enable, allow, encourage) tend to be textured with schools, which accords with the principle of school autonomy in the creation of an educational market of 'independent state schools' (Blair, 2005).

In the typology below managing actions are grouped into three subcategories, (tendentially) ranged along a cline of coercion ${ }^{12}$, and named according to the type of managerial role they construct for the government. In descending order of coerciveness, they are Overseer, Leader, and Facilitator. To the extent that managerialism is becoming an increasingly significant aspect of the art of governing, these categories help provide a more detailed picture of the type of managerialism the government employs, in what domains and with what people.

\section{Typology of Managing Actions}

[1] Overseer Ensure (that) -- does, Make sure (that) -- does

[2] Leader Require - to, Expect - to, Look to - to, Want - to, Envisage that - should, Urge - to, Encourage - to, Ask -- to, Invite -- to, Promote [+ nominalization meaning 'the doing of $\mathrm{X}$ by MA']

\section{[3] Facilitator}

\section{a) Ability}

Support - (to/in doing), Help - to, Facilitate - to, Let - do, Allow - to, Enable - to, (Transform/Enhance) the capacity of - to, Make it easier (for--) to,

\section{b) Opportunity}

Free -to, Give -(greater/more) freedom(s) to, Provide/Increase/widen the) opportunities for -- to, Provide for - to

The Overseer is the most coercive role, where the manager is in control of the managed actor's behaviour, seeing it through to completion. In other words, they encode the meaning 'without $\mathrm{X}, \mathrm{Y}$ wouldn't do it'. Completion of the activity is assumed semantically. The Leader role assumes the manager's authority to instigate others' actions, but the future orientation encoded semantically means there is no assumption of their completion. Finally the least coercive is the Facilitator role. Here the manager's authority over the managed actor is assumed, but completion of the action is not necessarily assumed. They encode the meaning 'without X, Y couldn't do it', for want of either ability or permission/opportunity. Here, the coercion works by assuming the managed actor is willing to act and as such, although on the surface the least coercive, is nevertheless a particularly hegemonic formulation.

\section{General Findings}

I used this typology to examine the use of these managing actions throughout the data. The results indicate a huge surge in their use from just 9 instances under Thatcher, to 43 under Major, to 358 under Blair. By 2005 they account for 20\% of all verbal 
collocates $^{13}$ of the government. Under Blair there is also a proliferation in the linguistic forms by which they are represented. The data for the governments prior to New Labour in fact contain very few managing actions, and are mainly semiotic (require, expect, look to), constructing a 'leader' role for the government, delegating responsibilities to various actors. Under Thatcher this is mainly used to remove powers from the Local Education Authorities, in an important move that prepared the ground for a more deregulated and market-based state education system. Under Major this 'hollowing out' of power from LEAs continues, alongside the use of managing actions to allow the government to oversee a wide range of actors and activities in securing greater economic competitiveness (see also Mulderrig, 2008 on the discourse of competitiveness under Major). Thus, the government will: 1) require LEAs to increase delegation to their schools; 2) expect LEAs to continue to make appropriate provision for such pupils; 3) encourage higher education institutions to make available information about the employment of new graduates, by subject, including if practicable details of average starting salary.

The most coercive action require permits little scope for resistance and is tantamount to an imperative. Conversely, rather greater compliance appears to be anticipated when it comes to LEAs continuing to provide for pupils with disabilities and special educational needs (example 2). In the third example, a median level of coercive effort is put into the attempt to stimulate the marketisation of universities. The next sentence in the document makes it clear that this is the purpose: This will help potential higher education students to make better informed decisions. The assumption is that what constitutes better information in selecting a university education is the long-term monetary returns it is likely to yield.

Despite the government's claims to 'offer an active, enabling government', it is interesting to note that its most textually prominent role, and by some margin, is actually that of the traditional manager. It uses its Leader role to oversee, benchmark and monitor others - types of activities that involve fewer freedoms for educational actors than the government makes claims to. Where for Major the emphasis was on competitiveness, under Blair this shifts to the strategy for securing it in a knowledge economy, namely skills - the highest-ranking keyword under this government.

\section{Blair the Overseer: strategic economic planning and modelling}

The single most frequently used managing verb is ensure, which constructs a steering role over both economic and educational practices. It does so by guaranteeing an abstract vision of excellence and success in both spheres. In an expansive, positively affective discourse, the government offers ever-widening opportunities for improvement, access, information, and participation. Thus [we will ensure that young people] develop knowledge and skills to take their place in society; achieve National Curriculum level 5; have some good quality engagement with employment; obtain the learning and skills they need to take on new challenges at work, or learn how to be creative and enterprising to generate ideas, products and innovations. The most frequently managed actors are young people or people generally, both of whom are steered into lifelong learning practices. These are construed as the keys to full participation in both work and society, illustrating the central role of educational practices in New Labour's Third Way alignment of social justice with economic participation. A wide range of actors and actions are managed by ensure, ranging from securing competitiveness in UK businesses to guaranteeing the rights of school governors to dismiss incompetent staff. In terms of contemporary governance, ensure 
thus appears to be a prominent textual mechanism for coordinating increasingly complex networks of activity across larger political and social spaces.

\section{Blair the Leader: delegating and coordinating}

In its leader role, the government is represented as institutionalisng and orchestrating joined up governance. It thus manages actors who are represented in terms of their organisational properties or functional remit. These include middle-tier governmental and non-governmental organisations, partnerships and other more-or-less abstract networks of actors (Education Action Zones, Regional Development Agencies, Learning and Skills Council, Sector Skills Development Agency, Local Forums, Local Strategic Partnerships, and the Skills for Business Network, LEAs). Such institutional actors are expected, asked and invited to engage in predominantly semiotic middlemanagement activities. Under Major prominent attention was given to the macro level economic goals, its leader role mainly shifting educational controls towards a hollowed out model, removing powers from the middle tier. The Blair government builds on this, elaborating a specifically skills-based growth strategy, developing new roles, relations and institutions of a networked or 'joined up' model of governance. This extends also to LEAs who, compared with the previous governments, are somewhat less coercively managed in new, different roles. To the extent that we can call the flows of power under Major a 'hollowing out' of the state, we might therefore characterise those under Blair as ‘filling in'.

\section{Blair the Facilitator: enabling neoliberal change}

The facilitated actors are institutions (schools, universities, colleges) occupationally represented actors (learners, heads, teachers, workers, employers, parents, trainers) or the sectorally defined business. The most frequent form of facilitating is support. While a variety of actions are managed by it, a recurrent theme is that of skills. Businesses are helped to succeed by focussing on the skills of their workforce, while learners and young people are supported in developing them, as are heads and middle managers. Thus, in what is in fact the most textually and politically prominent theme of the Blair data, the government supports a variety of actors to upgrade, acquire, develop, renew: (key, core, basic, advanced, professional, work-related) skills.

Meanwhile schools are helped to take on an increased range of responsibilities for securing both excellence and social inclusion. The government's facilitation of schools is textured with both a discourse of competitive marketisation and a more pastoral discourse of needs and social problems, construing a central role for schools in securing social inclusion. Thus on the one hand they will be helped to raise the quality of teaching and learning; deliver greater flexibility; meet the needs of talented and gifted children; develop further to become Centres of Excellence. While on the other hand, they will be helped to become healthy schools (this refers to pressing public health problems including smoking, drug and alcohol abuse) and meet the needs of children with special educational needs. Finally, we will [P] help schools $[\mathrm{M}]$ deliver this $[\mathrm{M}]$ focused $[\mathrm{P}]$ support (for young people who are struggling to reach, by age 14 , the required standard set for them in government targets). The represented actions in this example help texture a pastoral discourse [P] with the managerial $[\mathrm{M}]$, so that support and social inclusion become a matter of meeting external targets, even while still at school. 


\section{Summary}

In terms of contemporary governance, ensure appears to be a prominent textual mechanism for coordinating increasingly complex networks of activity across larger political and social spaces. While this permits greater governing at a distance, it doesn't necessarily imply a weakening of power, simply a change in how it is applied, for example by monitoring performance and emphasising desired outcomes. In terms of the evolution of managerial models of governance a distinctive pattern emerges from this analysis. The first two periods include very few managing actions. Under Thatcher they are used to remove powers from LEAs, suggesting a structural diagnosis of a problem in the existing bureau-professional model for governing education. Under Major, a broader economic and organisational vision of competitiveness is articulated through its Overseer role, alongside a continued removal of LEA powers. Under Blair, both the proliferation of managing actions and the way they are textured suggest that this economic vision of competitiveness has moved from the planning stage to its strategic enactment. And at the heart of this strategy are skills, which are represented as the central formula for both economic and social success. So central in fact, that the term is the highest ranking keyword in this period, occurring 1473 times. Indeed, in so far as skills represent a key element of labour power in a knowledge-based economy, under Blair education's role as the main producer of capitalist labour power is rendered more explicit than ever.

\section{Conclusion}

Many political economists and educational sociologists have commented that New Labour's policies contain strong ideological continuities with the preceding Conservative governments (Brivati \& Bale, 1997; Campbell \& Whitty, 2003; Hay, 1999; Jessop, 2002; 2006b). In this paper I have explored these neoliberal lines of continuity while at the same time illustrating its distinctiveness at the level of political rhetoric. As evidence for this claim I have provided a (necessarily schematic) overview of two key trends identified in New Labour's discourse of educational governance: 'personalisation' and 'managerialisation' (for a fuller treatment see Mulderrig, 2009b and 2009a respectively). Both relate to the government's mode of self-representation, respectively constructing its social identity and its social actions and power relation with others. Together, I argue, they help construct a more subtly hegemonic and managerial style of governance. Through close textual analysis of its policy discourse, informed through a political economic understanding of the historical context, it becomes apparent that New Labour displays a striking novelty in its policy discourse.

Despite the supposed shift towards a more devolved model of educational governance, this is clearly not a retreating government. In fact a marked point of comparison in the whole corpus is the huge surge under Blair in the textual prominence of the government; statistically it becomes the most prominent actor. This prominence is, however, masked to a considerable degree through its inclusive style of self-representation. This is by no means a neutral or insignificant textual choice, since the semantics of this pronoun allow the government to elide its own identity with that of the public, and thereby make claims on behalf of the entire nation. Indeed, the semantic slipperiness of this pronoun is systematically exploited in such a way as to implicate every one of us in the legitimation of government policy decisions. This government also displays the greatest linguistic inventiveness in enacting a 
managerial style of governing that affords far fewer freedoms than its own rhetoric would suggest. It was stated at the outset that the ways in which we routinely define ourselves individually and collectively position us and others as social subjects, thereby structuring social relations of power and domination. To the extent that the role of education policy is to negotiate the future of education on the basis of its imagined relationship with the wider socioeconomic order, and to (re)draw lines of individual and collective responsibility, I would argue that New Labour enacts this through a much more subtle form of hegemony.

\section{References}

Blair, T. (2005) Press conference, $24^{\text {th }}$ October, BBC 1.

Brivati, B, and Bale, T. (eds.) (1997) New Labour In Power: precedents and prospects (London: Routledge)

Campbell, C. and Whitty, G. (2003) From New Right To New Labour: What's New In English Education Policy?, Anglistik und Englischunterricht, 65: 101-122, Special edition: Britain under Blair (Heidelberg: Winter Verlag)

Chilton, P. (2004) Analysing Political Discourse: theory and practice (London: Routledge)

Chouliaraki, L. and Fairclough, N. (1999) Discourse in Late Modernity: rethinking critical discourse analysis (Edinburgh: Edinburgh University Press)

Clarke, J., and Newman, J. (1997) The Managerial State (London: Sage)

Dale, R. (1989) The State and Education Policy (Buckingham: Open University Press)

Dale, R. \& Robertson, S. (2006). The case of the UK: homo sapiens Europaeus vs homo quaestuosus Atlanticus? European learning citizen or Anglo-American human capitalist?, in: M. Kuhn \& R. Sultana (eds.), Creating the European Learning Citizen (New York: Peter Lang Publishing)

Department for Education and Skills (2005) 14 - 19 Education and Skills, White Paper (London: HMSO)

Fairclough, N. (1992) Discourse and Social Change (Oxford: Blackwell)

Fairclough, N. (2000) New Labour, New Language? (London: Routledge)

Fairclough, N. (2003) Analysing Discourse: Text Analysis for Social Research (London: Routledge)

Fairclough, N. (2005) Critical discourse analysis, Marges Linguistiques, 9: 76-94

Fairclough, N., Wodak, R., and Mulderrig, J. (2009 forthcoming) 'Critical Discourse Analysis', in: T. Van Dijk (ed.) Discourse Studies: a multidisciplinary introduction, ( $2^{\text {nd }}$ edn.) (London: Sage)

Foucault, M. (1971) L'Ordre du discours (Paris: Gallimard)

Graham, P. (2001) Space: irrealis objects in technology policy and their role in a new political economy, Discourse and Society, 12 (6) 761-788

Habscheid, S., and Knobloch, C. (2008) (eds.) Discourses of Unity: Creating Scenarios of Consensus in Public and Corporate Communication (Berlin: De Gruyter)

Halliday, M. A. K. (1994) An Introduction to Functional Grammar (2nd edition) (London: Edward Arnold)

Halliday, M. A. K. and Martin, J. R. (1993) Writing Science: literacy and discursive power (London: Falmer Press)

Hay, C. (1996) Re-stating Social and Political Change (Buckingham: Open University Press) 
Hay, C. (1999) The Political Economy of New Labour: labouring under false pretences? (Manchester: Manchester University Press)

Jessop, B. (1994) The Transition to Post-Fordism and the Schumpeterian Workfare State, in: R. Burrows and B. Loader (eds.), Towards a Post-Fordist Welfare State? (London: Routledge)

Jessop, B. (1999) The Changing Governance of Welfare: Recent Trends in its Primary Functions, Scale and Modes of Coordination, Social Policy and Administration, 33 (4) 348-359.

Jessop, B. (2002) The Future of the Capitalist State (Cambridge: Polity)

Jessop, B. (2006) From Thatcherism to New Labour: Neo-Liberalism, Workfarism, and Labour Market Regulation, published by the department of Sociology, Lancaster University at: http://www.comp.lancs.ac.uk/sociology/soc131rj.pdf (accessed 02/04/06)

Koller, V. and Mautner, G. (2004) Computer Applications in Critical Discourse Analysis, in: A. Hewings, C. Coffin and K. O’Halloran (eds.), Applying English Grammar (London: Arnold)

Martin, J. R. (1991) Nominalisation in Science and Humanities: distilling knowledge and scaffolding text, in: E. Ventola (ed.) Functional and Systemic Linguistics: Approaches and Uses (Berlin and New York: Mouton de Gruyter)

Mautner, G. (2005) Time to Get Wired: Using Web-Based Corpora in Critical Discourse Analysis, Discourse \& Society, 16 (6), 809-828.

Mautner, G. (2009) Checks and balances: how corpus linguistics can contribute to CDA'. In: R. Wodak and M.Meyer (eds.), Methods of Critical Discourse Analysis (London: Sage)

McEnery, T. and Wilson, A. (1996) Corpus Linguistics (Edinburgh: Edinburgh University Press)

Mulderrig, J. (2003a) Learning to Labour: the discursive construction of social actors in New Labour's education policy, Anglistik \& Englischunterricht (65)123145, Special edition: Britain under Blair (Heidelberg: Winter Verlag)

Mulderrig, J. (2003b) Consuming Education: a critical discourse analysis of social actors in New Labour's education policy, Journal of Critical Education Policy Studies 1 [http://www.jceps.com/index.php?pageID=article\&articleID=2]

Mulderrig, J. (2006) The Governance of Education: a corpus-based critical discourse analysis of UK education policy texts 1972-2005, (Lancaster: Lancaster University, doctoral thesis)

Mulderrig, J. (2007) Textual Strategies of Representation and Legitimation in New Labour Policy Discourse, in: A. Green, G. Rikowski, and H. Raduntz (eds.), Renewing Dialogues in Marxism and Education (London: Palgrave Macmillan) pp 135-150

Mulderrig, J. (2008) Using Keywords Analysis in CDA: evolving discourses of the knowledge economy in education, in: Jessop, B., Fairclough, N., and Wodak, R. (eds.), Education and the Knowledge-Based Economy in Europe (Rotterdam: Sense Publishers) pp 149-170

Mulderrig, J. (2009a, forthcoming) The Grammar of Governance, Critical Discourse Studies

Mulderrig, J. (2009b, forthcoming) The Hegemony of Inclusion: constructing the subjects of Third Way politics, Journal of Language and Politics

Muntigl, P., Weiss, G., and Wodak, R. (2000) European Union Discourses on Un/employment (Amsterdam: John Benjamins) 
Newman, J. (2000) Beyond the New Public Management? Modernising public services, in: Clarke, J., Gerwitz, S., and McLaughlin, E., (eds), New Managerialism, New Welfare? (London: Sage)

Newman, J. (2001) Modernising Governance: New Labour, policy and society (London: Sage)

Nye, J. (2004) Soft Power: The Means to Success in World Politics (New York: Public Affairs)

Petersoo, P (2007) What does 'we' mean? National deixis in the media, Journal of Language and Politics, 6 (3) 419-436

Rose, N. (1999) Inventiveness in politics, Economy and Society, 28 (3) 467-493

Scott, M. (1997) Wordsmith Tools, (Oxford)

Tomlinson, S. (2001) Education in a Post-welfare Society (Buckingham: Open University Press

Trowler, P. (2003). Education Policy, (2nd edition) (London: Routledge)

Van Leeuwen, T. (1995) Representing Social Action, Discourse and Society, 4 (2) 193-223

Van Leeuwen, T. (1996) The Representation of Social Actors, in: Caldas-Coulthard, C. R., and Coulthard M. (eds.), Texts and Practices: readings in critical discourse analysis (London: Routledge) pp 32-71

Van Leeuwen, T. (2007) Legitimation in discourse and communication, Discourse and Communication, 1 (1) 91-112.

Van Leeuwen, T. (1999) Discourses of Unemployment in New Labour Britain, in: R. Wodak, and L. Christoph (eds.), Challenges in a Changing World: issues in critical discourse analysis (Wien: Passagen-Verlag) pp 87-100

\footnotetext{
${ }^{1}$ I am grateful to the ESRC for funding this doctoral research.

${ }^{2}$ For a fuller account of the political economic context of this study, see Mulderrig, 2007; 2008.

${ }^{3}$ In corpus linguistics, 'keyness' refers to the statistical significance of a word's frequency relative to some norm.

${ }^{4}$ Following Halliday's social semiotic approach $(1978 ; 1994)$ we can classify the elements of a clause according to its Participants, Processes and Circumstances. Generally realised as verbs, Processes are sub-divided into sub-types, which map onto the three main realms of human activity doing, being, and sensing. Thus, they can be categorised as Material, Existential, Relational, Verbal, Mental, or Behavioural. The representation of the government's actions in the data is in fact frequently very complex, abstract and metaphorical. The analysis process itself therefore fed back into the development of descriptive tools, with additional models of description overlaid onto the analysis as it progressed. Thus, as I encountered classificatory problems using systemic functional tools, I drew additionally on Van Leeuwen's alternative model of representation $(1995,1996)$, and Graham's treatment of abstraction and metaphor in policy discourse (2001).

${ }^{5}$ In the linguistic study of lexical meaning, words may be analysed into a series of binary semantic features like ADULT/NON-ADULT, MALE/FEMALE. For example, the word man could be analysed as ADULT, HUMAN, MALE, while woman could be analysed as ADULT, HUMAN, FEMALE. These semantic components are conventionally presented as + or - the relevant feature (e.g. the word bull would be +ADULT, -HUMAN, -FEMALE).

${ }^{6}$ For a more extensive analysis of 'personalisation' under New Labour, see Mulderrig, 2009b.

${ }^{7}$ The only significant exception is the data for Thatcher, where the pronoun does make an appearance, albeit comparatively infrequently.

${ }^{8} 83 \%$ of cases of the pronoun refer specifically to the government itself, thus lending evidence to the claim that the government has become a significantly more prominent figure in education policy discourse (the most textually prominent actor by a considerable margin).
} 


\footnotetext{
${ }^{9}$ This result may also indicate the increased prominence of this textual strategy in public discourse more generally. Nevertheless, the stark contrast with the discursive style of the preceding government suggests that this is an important feature of New Labour discourse in particular.

${ }^{10}$ In corpus linguistics, 'concordance' lines display in a vertical list all occurrences of a particular search word in their textual environment. Here the search word was, of course, the pronoun we. These lines can be expanded to display more of the surrounding text; this step is necessary to analyse each occurrence in more detail.

${ }^{11}$ Using systemic functional grammar (Halliday, 1994), I categorised each instance according to the type of process (the verb) that we is responsible for - see note 3 above for more on this method.

${ }^{12}$ It is important to note that this typology has been derived in order to characterise the findings in the data examined; it is not intended as a universally applicable context-free grammar. Thus, for instance, the specific power relations underlying the social practice examined here were factored into the analysis. It would, however, be interesting to 'test' its interpretive capacity in other social contexts. Note also the typology only contains verbal collocates of we and the government. Thus other possible surface forms like nominalisations have been omitted.

${ }^{13}$ 'Collocates' are words that co-occur. Thus the verb co-occurring with we or the government is a managing action in a fifth of all cases under New Labour.
} 